\title{
Optimizing High Performance Self Compacting Concrete
}

\author{
Yonathan Raymond $\mathrm{A}^{1,{ }^{*}}$, Ekaputri Januarti Jaya ${ }^{1,2}$, and Triwulan ${ }^{2}$ \\ ${ }^{1}$ Civil Engineering Department, Faculty of Civil Engineering and Planning, Institut Teknologi \\ Sepuluh Nopember (ITS), Sukolilo, Surabaya, Indonesia \\ ${ }^{2}$ Konsorsium Riset Geopolimer Indonesia (KORIGI), Laboratorium Beton dan Bahan Bangunan, \\ Kampus ITS Sukolilo Surabaya, Indonesia, 60111
}

\begin{abstract}
This paper's objectives are to learn the effect of glass powder, silica fume, Polycarboxylate Ether, and gravel to optimizing composition of each factor in making High Performance SCC. Taguchi method is proposed in this paper as best solution to minimize specimen variable which is more than 80 variations. Taguchi data analysis method is applied to provide composition, optimizing, and the effect of contributing materials for nine variable of specimens. Concrete's workability was analyzed using Slump flow test, V-funnel test, and L-box test. Compressive and porosity test were performed for the hardened state. With a dimension of $100 \times 200$ $\mathrm{mm}$ the cylindrical specimens were cast for compressive test with the age of $3,7,14,21,28$ days. Porosity test was conducted at 28 days. It is revealed that silica fume contributes greatly to slump flow and porosity. Coarse aggregate shows the greatest contributing factor to L-box and compressive test. However, all factors show unclear result to V-funnel test.
\end{abstract}

\section{Introduction}

Condensed Silica Fume is now commonly used as a cementitious supplementary material in concrete [1]. It improves the strength of concrete and also the durability of concrete [2]. Using waste glass powder as supplementary material for cement is quite popular worldwide due to the increased disposal costs and environmental concern. It contains silica based material in amorphous form, and increase the strength of concrete [2-4]. It was also found promising to be added in Self compacting concrete mixture [5].

Previous study showed that using silica fume and glass powder as cement replacement could be used to gradually increase strength of concrete paste [6,7]. Self Compacting Concrete is well known for its workability, which can provide many advantages such as lower the rates of human error, doesn't need any compacting activities, can fill through narrow gaps, etc [8-13]. Using this previous study as reference, High Performance Self Compacting Concrete should be developed to increase the productivity and quality for the construction. It is complicated to optimize the mix design using trial and error, since it is time and energy consuming, therefore using statistic method is helpful to obtain more result

\footnotetext{
* Corresponding author: rayonathan@hotmail.com
} 
with less trial and error, since it is time and energy consuming, therefore using statistic method is helpful to obtain more result with less trial and error.

Fractional factorial designs was known as money and time saver statistical approach. Despite being widely and effectively used, this method become unwieldy in cost and time the number and variables is large, two designs for same experiments may resulting different results, and the interpretation of the experimental result with a large number of factors may be difficult due to lack of clear design and analysis guidelines. Genichi Taguchi of Japan proposed an innovative method by simplified and standardized fractional factorial designs, thus he able to overcome the limitation of fractional factorial designs. [14]

This paper discusses about the optimizing and the contributing factors of high performance self compacting concrete using Taguchi's single response method as the data analysis.

\section{Material}

Aggregates. The densities of coarse aggregate $( \pm 1.2 \mathrm{~cm})$ and fine aggregate are 2.74 $\mathrm{g} / \mathrm{cm} 3$ and $2.72 \mathrm{~g} / \mathrm{cm} 3$ respectively.

Superplasticizer. There were two kind of superplasticizer used in the mixture to achieve the workability of concrete, which are Polycarboxylate Ether and Polyhydroxy Carbon Salts. Polycarboxylate Ether was used in the controlled factors as shown in Table 1. Polyhydroxy Carbon Salts was used as additional superplaticizer with $0.2 \%$ from binders weight.

Binders. Ordinary Portland Cement (OPC) with specific gravity of $3.14 \mathrm{gr} / \mathrm{cm} 3$. Silica Fume with specific gravity of $2.105 \mathrm{gr} / \mathrm{cm} 3$. Waste ground glass with specific gravity of $2.381 \mathrm{gr} / \mathrm{cm} 3$. Ground glass need to be pulverized before applied as cement replacement, after that particle size distribution was conducted. Using glass powder with size in average of $25 \mu \mathrm{m}$ which its distribution as shown in Fig. 1.

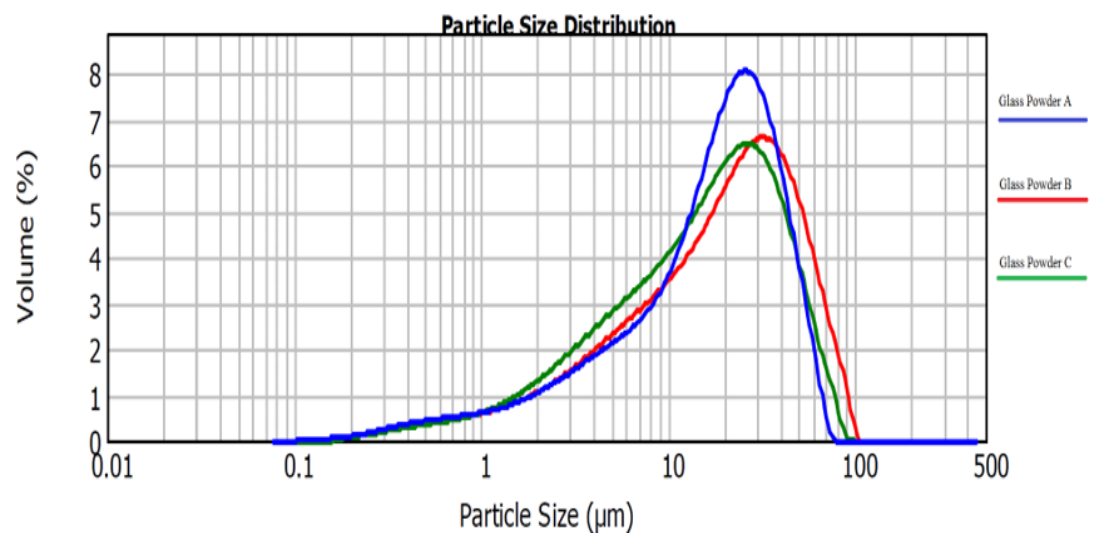

Fig. 1. Distribution of Glass Particles 


\section{Methods}

The composition of binders were determined from previous research [6,7]. Using Taguchi analysis method, the factors, levels, degrees of freedom, and orthogonal array need to be determined to generate the mix design $[14,15]$ as shown in Table 1, Table 2, Table 3, and Table 4 respectively. Using glass powder $(10 \%, 15 \%, 20 \%$ from total weight of cement plus glass powder), silica fume $(20 \%, 40 \%, 60 \%$ from total weight of glass powder plus silica fume), Polycarboxylate Ether $(0.8 \%, 1 \%, 1.2 \%$ from binder's weight), and coarse aggregate $(45 \%, 50 \%, 55 \%$ from total volume of aggregate) as the controlled factors.

Table 1. Factors and Level

\begin{tabular}{|c|l|c|c|c|}
\hline \multirow{2}{*}{ Codes } & \multirow{2}{*}{ Controlled Factors } & Level 1 & Level 2 & Level 3 \\
\cline { 3 - 5 } & & $\mathbf{( \% )}$ & $\mathbf{( \% )}$ & $\mathbf{( \% )}$ \\
\hline A & Coarse Agregate & 45 & 50 & 55 \\
\hline B & Glass Powder & 10 & 15 & 20 \\
\hline C & Silica Fume & 20 & 40 & 60 \\
\hline D & Polycarboxylate Ether & 0.8 & 1 & 1.2 \\
\hline
\end{tabular}

Table 2. Degree of Freedom

\begin{tabular}{|c|c|}
\hline Factors & DF \\
\hline A & 2 \\
\hline B & 2 \\
\hline C & 2 \\
\hline D & 2 \\
\hline Total & 8 \\
\hline
\end{tabular}

Table 3. Orthogonal Array L9 $\left(3^{4}\right)$

\begin{tabular}{|c|c|c|c|c|}
\hline Codes & A & B & C & D \\
\hline R1 & 1 & 1 & 1 & 1 \\
\hline R2 & 1 & 2 & 2 & 2 \\
\hline R3 & 1 & 3 & 3 & 3 \\
\hline R4 & 2 & 1 & 2 & 3 \\
\hline R5 & 2 & 2 & 3 & 1 \\
\hline R6 & 2 & 3 & 1 & 2 \\
\hline R7 & 3 & 1 & 3 & 2 \\
\hline R8 & 3 & 2 & 1 & 3 \\
\hline R9 & 3 & 3 & 2 & 1 \\
\hline
\end{tabular}


Table 4. Mix Design

\begin{tabular}{|c|c|c|c|c|c|c|c|c|}
\hline Codes & $\begin{array}{c}\text { Cement } \\
\left(\mathbf{k g} / \mathbf{m}^{\mathbf{3}}\right)\end{array}$ & $\begin{array}{c}\text { Glass } \\
\text { Powder } \\
\left(\mathbf{k g} / \mathbf{m}^{\mathbf{3}}\right)\end{array}$ & $\begin{array}{c}\text { Silica } \\
\text { Fume } \\
\left(\mathbf{k g} / \mathbf{m}^{\mathbf{3}}\right)\end{array}$ & $\begin{array}{c}\text { Water } \\
\left(\mathbf{L i t e r} / \mathbf{m}^{\mathbf{3}}\right)\end{array}$ & $\begin{array}{c}\text { Polycarboxylate } \\
\text { Ether }\left(\mathbf{l i t e r} / \mathbf{m}^{\mathbf{3}}\right)\end{array}$ & $\begin{array}{c}\text { Polyhydroxy } \\
\text { Carbon Salts } \\
\left(\mathbf{L i t e r} / \mathbf{m}^{\mathbf{3}}\right)\end{array}$ & $\begin{array}{c}\text { Fine } \\
\text { Agregate } \\
\left(\mathbf{k g} / \mathbf{m}^{\mathbf{3}} \mathbf{)}\right.\end{array}$ & $\begin{array}{c}\text { Coarse } \\
\text { Agregate } \\
\left(\mathbf{k g} / \mathbf{m}^{\mathbf{3}}\right)\end{array}$ \\
\hline R1 & 612.75 & 54.47 & 13.62 & 170.21 & 5.11 & 1.36 & 897.6 & 739.8 \\
\hline R2 & 569.85 & 60.34 & 40.22 & 167.6 & 6.29 & 1.34 & 897.6 & 739.8 \\
\hline R3 & 527.27 & 52.73 & 79.09 & 164.77 & 7.43 & 1.32 & 897.6 & 739.8 \\
\hline R4 & 607.73 & 40.52 & 27.01 & 168.81 & 7.61 & 1.35 & 816 & 822 \\
\hline R5 & 570.06 & 40.24 & 60.36 & 167.67 & 5.04 & 1.34 & 816 & 822 \\
\hline R6 & 532.79 & 106.56 & 26.64 & 166.5 & 6.25 & 1.33 & 816 & 822 \\
\hline R7 & 608.53 & 27.05 & 40.57 & 169.04 & 6.35 & 1.35 & 734.4 & 904.2 \\
\hline R8 & 569.63 & 80.42 & 20.1 & 167.54 & 7.55 & 1.34 & 734.4 & 904.2 \\
\hline R9 & 532.5 & 79.88 & 53.25 & 166.41 & 5 & 1.33 & 734.4 & 904.2 \\
\hline
\end{tabular}

Fresh concretes were tested for slump flow test, V-funnel test, and L-box test [16]. After that, the fresh concrete was casted in cylindrical molds with a diameter of 100 and $200 \mathrm{~mm}$ high [17]. One day after casting, concretes were cured in water (wet curing system) until the age of $3,7,14,21$, and 28 days to be tested for compressive strength. One day before compressive test, the rough top surface of concrete was cut to obtain smooth and solid surface. The compressive test is corrected using correction factor, since length of cylinder may be less than initial condition $[18,19]$. Porosity test conducted at the age of 28 days.

\section{Results and discussions}

Concrete's test result is shown by Table 5 .

Table 5. Test Results

\begin{tabular}{|c|c|c|c|c|c|}
\hline Codes & $\begin{array}{c}\text { Compressive Strength on } \\
\text { 28 Days }\end{array}$ & Slump & V-Funnel & L-Box & $\begin{array}{c}\text { Total } \\
\text { Porosity }\end{array}$ \\
\hline & $\mathbf{( M P a )}$ & $\mathbf{( c m )}$ & $\mathbf{( s )}$ & & $\mathbf{( \% )}$ \\
\hline R1 & 56.34 & 79.5 & 8.17 & 0.83 & 17.93 \\
\hline R2 & 53.2 & 72.5 & 12.3 & 0.79 & 15.51 \\
\hline R3 & 40.98 & 69.5 & 7.1 & 0.83 & 20.89 \\
\hline R4 & 42.93 & 71 & 11.8 & 0.76 & 16.11 \\
\hline R5 & 45.99 & 68.5 & 14 & 0.73 & 24.57 \\
\hline R6 & 42.76 & 80.5 & 8.3 & 0.82 & 18.5 \\
\hline R7 & 32.16 & 73.5 & 12.94 & 0.78 & 29.02 \\
\hline R8 & 22.35 & 79 & 37.37 & 0.8 & 21.95 \\
\hline R9 & 31.82 & 71 & 8.81 & 0.79 & 22.71 \\
\hline
\end{tabular}


Taguchi data analysis is applied for Slump flow test, V-funnel test, L-box test, Compressive test, and Porosity test with $85 \%$ of confidence level. Analysis result is shown by Table 6 .

Table 6. Taguchi's data result (single response)

\begin{tabular}{|c|c|c|c|c|c|}
\hline Test & $\begin{array}{c}\text { Coarse } \\
\text { Aggregate }\end{array}$ & $\begin{array}{l}\text { Glass } \\
\text { Powder }\end{array}$ & $\begin{array}{l}\text { Silica } \\
\text { Fume }\end{array}$ & $\begin{array}{c}\text { Polycarboxylate } \\
\text { Ether }\end{array}$ & $\begin{array}{c}\text { Estimated } \\
\text { optimum } \\
\text { Condition }\end{array}$ \\
\hline $\begin{array}{l}\text { Slump flow } \\
\text { (cm) }\end{array}$ & $55 \% * *$ & $10 \%$ & $20 \% *$ & $1 \% *$ & $78.778 \pm 2.040 \mathrm{~cm}$ \\
\hline L-Box & $55 \% *$ & $15 \% *$ & $40 \% *$ & $1 \% * *$ & $0.760 \pm 0.030$ \\
\hline V-Funnel (s) & $45 \%$ & $20 \%$ & $40 \% * *$ & $1 \%$ & - \\
\hline $\begin{array}{l}\text { Compressive } \\
\text { Strength } \\
\text { (MPa) }\end{array}$ & $45 \% *$ & $10 \%$ & $40 \% * *$ & $0.8 \% *$ & $\begin{array}{c}54.037 \pm 5.496 \\
\mathrm{MPa}\end{array}$ \\
\hline Porosity (\%) & $45 \% *$ & $15 \% * *$ & $40 \% *$ & $1.2 \% *$ & $14.274 \pm 0.677 \%$ \\
\hline \multicolumn{3}{|c|}{ Note: $(*)$ Significant Factor } & & & \\
\hline \multicolumn{2}{|c|}{ (**) Pooled Factor } & & & & \\
\hline
\end{tabular}

Slump Flow. It is found that Silica Fume contributes greatly to slump flow with contribution percentage $88.88 \%$ followed by Polycarboxylate Ether with contribution percentage $5.74 \%$. Applying $55 \%$ of coarse aggregate, $10 \%$ of glass powder, $20 \%$ of silica fume, and $1 \%$ of Polycarboxylate Ether to achieve optimum slump flow with $78.8 \pm 2.04$ $\mathrm{cm}$.

This result agreed with previous study [5-7] that Silica Fume absorb more water than glass powder. Adding more silica fume resulted in fresh concrete more condensed. In addition, adding glass powder shows better workability. It was noted that in R6 and R8 bleeding occurred, which contains higher glass powder. It is proved that adding glass powder cannot reduce bleeding.

V-Funnel. It is found that no factors have significant effect on the V-funnel. Which means that there are other factors or other levels that may have significant effect on V-funnel that were not estimated during the experiments. The optimum condition could not be estimated, however the composition can still be used.

L-Box. It is found that coarse aggregate contributes greatly to L-box with contribution percentage $27.44 \%$ followed by silica fume with contribution percentage $26.16 \%$, and then glass powder with contribution percentage $25.47 \%$. Applying $55 \%$ of coarse aggregate, $15 \%$ of glass powder, $40 \%$ of silica fume, and $1 \%$ of Polycarboxylate Ether to achieve optimum L-box with $0.76 \pm 0.03$.

This result agreed with previous study [8,9] that composition of mortar plays an important role in making self compacting concrete.

Compressive Strength. It is found that coarse aggregate has the biggest effect on the compressive strength with contribution percentage $76.35 \%$ followed by Polycarboxylate 
Ether with contribution percentage $14.42 \%$. Applying $45 \%$ of coarse aggregate, $10 \%$ of glass powder, $40 \%$ of silica fume, and $0.8 \%$ of Polycarboxylate Ether to achieve optimum compressive strength with $54.037 \pm 5.496 \mathrm{MPa}$.

This result agreed with previous study [6,7] that the use of Glass powder and Silica Fume can improves the strength because of Glass Powder is more reactive than Silica Fume, with recommendation amount $10-15 \%$ Glass Powder replacement to Cement, and $40 \%$ of Silica Fume replacement to Glass Powder. By using $45 \%$ of coarse aggregate, the compressive strength increases due to the smaller void or porous reducing in the concrete.

There is bubble occurred when mixing the concrete, especially on R8 where badly bubbled. It has not been confirmed what the cause of the bubble. Which lead to cutting the surface of cylinders before tested.

Porosity. It is found that silica fume has the biggest effect on the porosity with contribution percentage $50.23 \%$ followed by coarse aggregate with contribution percentage $44.82 \%$, and then Polycarboxylate Ether with contribution percentage $4.34 \%$. Applying $45 \%$ of coarse aggregate, $15 \%$ of glass powder, $40 \%$ of silica fume, and $1.2 \%$ of Polycarboxylate Ether to achieve optimum total porosity with $14.274 \pm 0.677 \%$.

Glass powder and silica fume have smaller particle size than cement and also lowering coarse aggregate's percentage, the optimum composition used high percentage of smaller materials to achieves the lowest percentage of porous. Which means by lowering the porous of concrete could increase the compressive strength [20,21]. It was found that by using high range water reducer and microsilica could decreased porosity [2], but by increasing high range water reducer could also decrease compressive strength.

\section{Summary}

It is revealed that silica fume shows the greatest contribution in Slump flow and Porosity test. However, coarse aggregate shows more contribution in L-box and Compressive test. Applying $55 \%$ of coarse aggregate, $10 \%$ of glass powder, $20 \%$ of silica fume, and $1 \%$ of Polycarboxylate Ether can achieve optimum slump flow at $78.8 \pm 2.04 \mathrm{~cm}$. Optimum L-box test result at $0.76 \pm 0.03$ can be achieved by applying $55 \%$ of coarse aggregate, $15 \%$ of glass powder, $40 \%$ of silica fume, and $1 \%$ of Polycarboxylate Ether. Optimum compressive strength at $54.037 \pm 5.496 \mathrm{MPa}$ can be achieved by applying $45 \%$ of coarse aggregate, $10 \%$ of glass powder, $40 \%$ of silica fume, and $0.8 \%$ of Polycarboxylate Ether. Applying $45 \%$ of coarse aggregate, $15 \%$ of glass powder, $40 \%$ of silica fume, and $1.2 \%$ of Polycarboxylate Ether can achieve optimum total porosity at $14.274 \pm 0.677 \%$.

Using $40 \%$ of silica fume by glass powder weight is recommended. In addition, $10-15 \%$ of glass powder is also recommended. Since the density of silica fume is less than glass powder, it influence the performance of fresh state of concrete. Hence, bleeding of concrete can be avoided.

Applying $1 \%$ of Polycarboxylate Ether is recommended to achieve better workability. Furthermore, to obtain less porous in concrete, it is recommended to use superplasticizer up to $1.2 \%$ because it can produce denser concrete. In consequences, it decrease the strength.

It is proved that controlling the volume of coarse aggregate plays an important role to produce high performance concrete in hardened state. Less coarse aggregate leads to compacted concrete.

\section{References}

1. E.H. Kadri, R. Duval, S. Aggoun, S. Kenai, ACI Struct. J., 106(2), 107 (2009) 
2. K. Wille, A.E. Naaman, G.J. Parra Montersinos, ACI Struct. J., 108(1), 46 (2011)

3. J.M. Khatib, E.M. Negim, H.S. Sohl, N. Chileshe, Eur. J. Appl. Physiol., 4(4), 173 (2012)

4. A. Shayan, A. Xu, Cem. Concr. Res., 36(3), 457 (2006)

5. M. Liu, Constr. Build. Mater., 25 (2), 919 (2010)

6. H. Limantono, J.J. Ekaputri, Triwulan, Key Eng. Mater. ,673, 37 (2016)

7. J.J. Ekaputri, H. Limantono, S. Susanto, Eddy, Triwulan, B. Abdullah, MM. AI, Key Eng. Mater., 673, 83 (2016)

8. H. Okamura, M. Ouchi, J. Adv. Concr. Technol., 1(1), 5 (2003)

9. H. Brouwers, H. Radix, Cem. Concr. Res., 35(11), 2116 (2005)

10. S. Dhiyaneshwaran, P. Ramanathan, I. Baskar, R. Venkatasubramani, Jordan, J. Civ. Eng., 7(3), 342 (2013)

11. C.F. Ferraris, L. Brower, C. Ozyildirim, J. Daczko, Proceedings of the international symposium on high performance concrete, 398 (2000)

12. O. Gencel, C. Ozel, W. Brostow, G. Martinez Barrera, Mater. Res. Innov., 15(3), 216 (2011)

13. Z. Grdic, I. Despotovicc, G. Topliccic CCurccic, Facta universitatis-series: Architecture and Civil Engineering 6(2), 173 (2008)

14. R.K. Roy, A Primer on the Taguchi Method (Society of Manufacturing Engineers, U.S.A, 2010)

15. R.K. Roy, Design of Experiments Using the Taguchi Approach: 16 Steps to Product and Process improvement (John Wiley \& Sons, New York, 2001)

16. F. Aslani, Mag. Concrete. Res., 65(15), 914 (2013)

17. ASTM C 192/C 192M - 02, Standard practice for making and curing concrete test specimens in the laboratory (ASTM International, West Conshohocken, 2002)

18. ASTM C 39/C $39 \mathrm{M}-01$, standart test method for compresive strength of cylindrical concrete specimen (ASTM International, West Conshohocken, 2001)

19. ASTM C 42M - 03, Standart test method for obtaining and testing drilled cores and sawed beams of concrete (ASTM International, West Conshohocken, 2003)

20. M. Rashid, M. Mansur, J. Civ. Eng., 37(1), 53 (2009)

21. A. Logan, W. Choi, A. Mirmiran, S. Rizkalla, P. Zia, ACI Struct. J., 106(5), 413 (2009) 